\title{
WHAT CAN WE LEARN FROM THE IMITATION OF CHRIST OF THOMAS A KEMPIS?
}

\author{
Tirza Juvina Rachmadi \\ Theologische Universiteit Kampen, the Netherlands \\ Korespondensi: tjrachmadi@gmail.com
}

\begin{abstract}
This article seeks to promote an interest of the audience to read the Imitation of Christ, the second most read book by both Protestants and Roman Catholics after the Bible. The book is dated to pre-Reformation time and provides fruitful soil for the Reformation by keeping close to the Scripture and the primacy of Christ. The book's three main motives sound strangely familiar to modern ears: the basic pairs of opposition coloring the current fabric of reality, the sovereignty of God, and the obedience of God's people. Even today the book remains fresh with its honesty and practical value, despite its being firmly grounded in doctrinal rocks.
\end{abstract}

KEYWORDS: Imitation of Christ; Thomas a Kempis; practical theology

\begin{abstract}
ABSTRAK: Artikel ini bertujuan membangunkan minat para pembaca pada buku the Imitation of Christ. Setelah Alkitab, buku ini adalah buku kedua yang paling banyak dibaca oleh baik orang Roma Katolik maupun orang Protestan. Waktu penulisan buku ini adalah pra-Reformasi dan menyediakan tanah gembur bagi Reformasi, dengan kesetiaan mengikuti Alkitab dan keutamaan Kristus. Buku ini memiliki tiga motif utama yang anehnya tidak terdengar asing bagi telinga modern: pasangan oposisi dalam tenunan realita saat ini, kedaulatan Allah, dan ketaatan umat Allah. Hari ini pun buku ini tetap segar dengan kejujuran dan nilai praktisnya, meski tertanam teguh dalam batu doktrinal.
\end{abstract}

KATA KUNCI: Imitation of Christ; Thomas a Kempis; teologi praktis

Some background of the author, the time and occasion of the writing is offered here, as well as a short theological analysis of the content, which consists of its theological importance, influence, and relevance for today. 


\section{Author}

There has been a debate surrounding the authorship of this famous work. One view holds that Thomas a Kempis was a translator of the work, which is composed by multiple writers who were all members of the Brotherhood of the Common Life. ${ }^{1}$ The different styles in the titles of each half of the Imitation (see Summary of Content) could be indicative of the presence of more than one author, but is not necessarily the case. A single author may change his style from one book to the other. It is possible that the content of one single book is written in the same period of time in which one particular writing styled is employed.

Another view names three of the most likely candidates: John Gerson, chancellor of the University of Paris; John Gersen, the reputed abbot of Vercelli, Italy, who lived about 1230; and Thomas. ${ }^{2}$ The arguments in favour for Kempis are as following: ${ }^{3}$ external witnesses, manuscripts and editions, and the similarity in style.

History of the Church provided the following information: ${ }^{4}$ Thomas a Kempis, 1380-1471, was born in Kempen, Germany, and died in Zwolle, the Netherlands. His paternal name was Hemerken. He was influenced by Gerrit de Groote, one of the founders of the Brotherhood of the Common Life. It was not officially recognized by the church and did not have perpetual vows. But in common with the other monasteries, the members left their possessions and did not marry. This "order" started with Groote gathering manuscript copyists. To support the houses, the brothers worked; besides preaching, teaching, and copying, their duties consisted of gardening, making clothes, and other occupations pertaining to the daily life. Thomas seemed to have a quiet life, devoted to meditation, composition and copying (he copied the Bible at least four times). ${ }^{5} \mathrm{He}$ was fond of quiet, and his motto is ama nesciri, which means "love to be unknown." This would shed some illumination as to why finding the author of the Imitation (if it was Thomas) was so difficult - he wanted to remain anonymous.

Kempis, de Groote, and his mentor, Ruysbroeck, who influenced de Groote, were all part of a stream of German mysticism. ${ }^{6}$ During that time the Roman Catholic church was in disarray over the conflicts between the Pope

\footnotetext{
1 Thomas a Kempis, “The Imitation of Christ," trans. Aloysius Croft and Harold Bolton (The Catholic Primer, 2004), 4, https://d2y1pz2y630308.cloudfront.net/15471/documents/2016/10/Thomas\%20A\%20 Kempis-The\%20Imitation\%20of\%20Christ.pdf (accessed July 8, 2018).

2 Philip Schaff, History of the Christian Church, Volume VI: The Middle Ages. A.D. 1294-1517, (Grand Rapids, MI: Christian Classics Ethereal Library, 1998), 236.

3 Ibid., 238-239.

$4 \quad$ Ibid., 228, 234-235, 236.

5 Ibid., 235.

6 Ibid., 195.
} 
and the King, between one Pope and another Pope, and so on. ${ }^{7}$ Scholasticism was languishing. ${ }^{8}$ This mysticism, defined shortly as the love of God shed abroad in hearts, prepared the way for Reformation. ${ }^{9}$

\section{Occasion}

Percy Fitzgerald thought the Imitation to be a spiritual diary ${ }^{10}$ but also by the way of a critic for fellow monks. ${ }^{11}$ The author of this article agrees that the work could well be a personal journal ${ }^{12}$, for there are places where a clear personal context can be traced. For instance, in book 3, chapter 19 begins with the voice of Christ asking, "What are you saying, My child?" without any previous hint as to what the author of the Imitation (called as the Disciple starting from book 3) was referring to. Christ's voice later explained the occasion of this chapter, namely being wronged by someone who has already accused him of many things. This order is suggestive of someone writing to face a personal problem he is struggling with and not taking time to explain the problem which he is well acquainted with.

The author of this article disagrees that the work is a critic towards fellow monks. It seems that the author is firmly convinced that it is better "to leave to every man to his own opinion than to take part in quarrelsome talk."13

\section{Summary of Content}

"Imitation of Christ" consists of four books. The published orders as we know them now are not necessarily the same as the ones arranged by the author. The preface in the edition used for this article announces the reversal of the order of book 3 and 4 . In its current stage, the titles of the books are: (1) Thoughts Helpful in the Life of the Soul, (2) The Interior Life, (3) Internal Consolation, and (4) An Invitation to Holy Communion. The third book has the biggest number of chapters (89) and introduces a new style that differs from the first two, namely the voice of Christ in dialogue with the disciple. The chapters' titles of book three and four also somewhat differ from the more succinct ones in book one and two. They are more like sentences, for

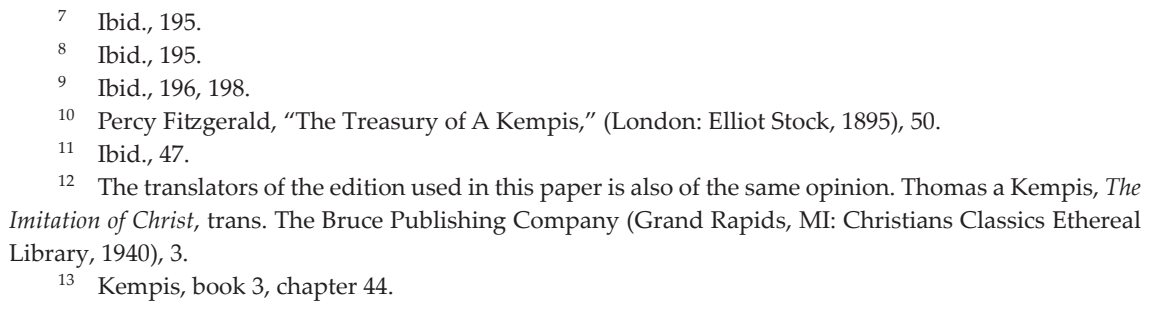

12 The translators of the edition used in this paper is also of the same opinion. Thomas a Kempis, The Imitation of Christ, trans. The Bruce Publishing Company (Grand Rapids, MI: Christians Classics Ethereal

13 Kempis, book 3, chapter 44. Library, 1940), 3. 
instance: "Truth Speaks Inwardly Without the Sound of Words" or "Listen Humbly to the Words of God. Many Do Not Heed Them."

As for the content, it is quite difficult to divide it according to the book numbers. ${ }^{14}$ There are motives which can be found all over the four books and are closely interwoven with each other:

1. The primacy of Christ over against the world's vanities.

2. The sovereign God, who manifests His sovereignty in both the grace and, especially, suffering experienced by believers.

3. Encouragements to obey throughout suffering.

More about the three motives:

1. The title of the first chapter in the first book (Imitating Christ and Despising all Vanities on the Earth) is foretelling of the contrast which runs through the veins of the whole book. Without it the book would lose its unique personality. This contrast is similar to the biblical concept of Old Man/New Man or Flesh/Spirit, but Kempis' applications are countless. It consists, for instance, in trusting God alone/trusting men, in looking for the eternal/temporal honor, in being humble/proud, etc. One name Kempis gives to this opposition is Nature/Grace. ${ }^{15}$ To differentiate it from the same term Aquinas coins to denote something else, the contrast will be called "imitation/non-imitation" henceforth. To the author of this article, it seems that this imitation/non-imitation is characterized by its visibility/invisibility to the natural human eyes. This division based on visibility can be found in the first chapter of the book. "Try, moreover, to turn your heart from the love of things visible and bring yourself to things invisible. For they who follow their own evil passions stain their consciences and lose the grace of God."16

2. Closely connected to the first motive is the sovereignty of God, which is manifest in both grace and sufferings experienced by believers. God's good pleasure, wisdom, and good will must be accepted, not merely by mouth or as theory, but by cultivating patience and humility in receiving whatever gift He sends. The words of Kempis are worth quoting: "[I]f you but look to the dignity of the Giver, no gift will appear too small or worthless."17 Here he is speaking about grace as well as punishments and scourges.

14 The subject index at the end of the edition used in this paper indicates this difficulty. They are: adversity, death, obedience, recollection, temptation, and communion.

15 Kempis, book 3, chapter 54.

16 Kempis, book 1 , chapter 1.

17 Kempis, book 2, chapter 10. 
Sufferings are often praised as good because they train believers in humility and push them nearer to God. "It is good for us to have trials and troubles at times .... It is good for us sometimes to suffer contradiction, to be misjudged by men even though we do well and mean well. These things help us to be humble .... [W] are more inclined to seek God Who sees our hearts." ${ }^{18} \mathrm{He}$ even goes on to say that there is nothing more useful to our salvation than suffering. ${ }^{19}$

3. Encouragements to obey can be found on almost every page. This book is dedicated to move its readers, and is explicitly against mere curiosity. Already in the first chapter, Kempis asks, "What good does it do to speak learnedly about the Trinity if, lacking humility, you displease the Trinity? Indeed it is not learning that makes a man holy and just, but a virtuous life makes him pleasing to God. I would rather feel contrition than know how to define it. For what would it profit us to know the whole Bible by heart and the principles of all the philosophers if we live without grace and the love of God?" ${ }^{20}$ Obedience in suffering is to be done with eyes directed towards the afterlife and the God who deals every man his portion. "For the truly patient man does not consider from whom the suffering comes, whether from a superior, an equal, or an inferior, whether from a good and holy person or from a perverse and unworthy one; but no matter how great an adversity befalls him, no matter how often it comes or from whom it comes, he accepts it gratefully from the hand of God, and counts it a great gain."21

This is how the three motives are interconnected. The first motive presents us with the pair of oppositions woven in the fabric of present reality. Nothing is neutral. The second shows that God remains sovereign above all, even above both suffering and happiness. In fact, suffering helps us to grow more steadfast in hoping for the invisible good, God. The third reminds us to be faithful in suffering by offering obedience to the sovereign God, the giver of all, including suffering.

Closely connected to the whole Imitation of Christ is a sub-motive worthy of our attention, namely monasticism. This book is written by a member (or members, in case the theory of multiple authors is correct) of the monastic life. It is also likely that it is meant for an audience from the

18 Kempis, book 1, chapter 12.

Kempis, book 2, chapter 12.

Kempis, book 1 , chapter 1 .

21 Kempis, book 3, chapter 19. 
same circle. ${ }^{22}$ Throughout the book, the general assumption is that monastic life is the way of imitating Christ, the way which abandons what is visible. A Bible verse is quoted in that connection, Luke 14:33, which is taken to mean that renouncing all that one possesses is to be done in the monastic way of life. ${ }^{23}$ Therefore praises for the ones having committed themselves to monasticism are abundant, while standing in contrast to it is the other way of living in the world, outside the walls of a monastery. "Vicious pleasure overcomes the soul that is given to the world. She thinks that there are delights beneath these thorns, because she has never seen or tasted the sweetness of God or the internal delight of virtue. They, on the other hand, who entirely despise the world and seek to live for God under the rule of holy discipline, are not ignorant of the divine sweetness promised to those who truly renounce the world." ${ }^{24}$ The critic addressed to the Imitation of Christ is connected to this specific character of monasticism, that it "presents only one side of the Christian life." 25

Despite this heavy monastic tone, the Imitation has made it to the top of the list of Christian bestsellers of all times. Some say of it that it is the book most read by Christians after the Bible. ${ }^{26}$ By Christians here is meant both Roman Catholics and Protestants, which is curious. A treatise from the same stream of movement, the German Theology, experienced a completely different fate; it was put into the Index, that is, the list of books forbidden for the Roman Catholics. ${ }^{27}$ Fitzgerald called Protestants who read the Imitation to be inconsistent, deeming the book to be uniquely Roman Catholic. Indeed there are traits in the work that are specifically Roman Catholic, like the doctrine of purgatory, ${ }^{28}$ or veneration of the saints. ${ }^{29}$ But they are "like the flecks on the marbles of the Parthenon," meaning they are very rare. ${ }^{30}$

The Imitation of Christ is pre-Reformation, and so the fearful tones of that age's disposition can be found in it. Here is one example of lamentation that would sound foreign to the present Protestant ears: "LORD, I am not worthy of Your consolation or of any spiritual visitation. Therefore, You treat me justly when You leave me poor and desolate. For though I could shed a sea of tears, yet I should not be worthy of Your consolation. Hence, I deserve only to be scourged and punished because I have offended You

22 Schaff, 234.

23 Kempis, book 4, chapter 8.

24 Kempis, book 3, chapter 20.

25 Schaff, 233.

26 Fitzgerald, 2.

27 Schaff, 241.

28 Kempis, book 3, chapter 12.

29 Kempis, book 3, chapter 6, 58.

30 Schaff, 234. 
often and grievously, and have sinned greatly in many things." ${ }^{31}$ Or another example of self-abasement, also rare in the modern times: "YOU thunder forth Your judgments over me, Lord. You shake all my bones with fear and trembling, and my soul is very much afraid. I stand in awe as I consider that the heavens are not pure in Your sight. If You found wickedness in the angels and did not spare them, what will become of me? Stars have fallen from heaven, and I-I who am but dust-how can I be presumptuous? They whose deeds seemed worthy of praise have fallen into the depths, and I have seen those who ate the bread of angels delighting themselves with the husks of swine." ${ }^{\prime 32}$

Despite the trait found in common with the Middle Ages' tendency, the Imitation paints the salvation firmly. "What do you especially demand of a guilty and wretched sinner, except that he be contrite and humble himself for his sins? In true sorrow and humility of heart hope of forgiveness is born, the troubled conscience is reconciled, grace is found, man is preserved from the wrath to come, and God and the penitent meet with a holy kiss." ${ }^{\prime 3}$ The Imitation of Christ sounds advanced, ahead of its time, almost a precursor to the Reformation's certainty of salvation.

How did the author become so certain? The answer lies in the primacy of Christ, and therefore "Protestants cherish it as well as Catholics." 34 "But it [the present life] has also more consolation than formerly under the old law when the gates of heaven were closed, when the way thereto seemed darker than now, and when so few cared to seek the eternal kingdom. The just, the elect, could not enter heaven before Your sufferings and sacred death had paid the debt." ${ }^{35}$ The just, the "meritorious" ones, cannot be saved unless Christ paid their debt through His suffering and death. This shows a faithfulness to the Scriptures shining forth unhindered by the Zeitgeist.

One last comment on book 4 regarding the Sacrament. The author compares relics to Christ. The practice of adoring relics is not unusual for that time. What is unusual, though, that the author then bursts forth in admiration for Christ, not the relics. "Many people travel far to honor the relics of the saints .... Often in looking at such things, men are moved by curiosity, by the novelty of the unseen, and they bear away little fruit for the amendment of their lives.... But here in the Sacrament of the altar You are wholly present, my God, the man Christ Jesus, whence is obtained the full 
realization of eternal salvation, as often as You are worthily and devoutly received. To this, indeed, we are not drawn by levity, or curiosity, or sensuality, but by firm faith, devout hope, and sincere love." ${ }^{36}$ In the last book the confession of $\sin$ is elaborated upon, ${ }^{37}$ and union with Christ celebrated. ${ }^{38}$

\section{Theological Importance}

When the word "theology" comes up, the first association that leaps to some people's mind is doctrinal teaching. But the Imitation of Christ is first of all practical theology. De Groote and Kempis provide the more practical aid, in comparison to Ruysbroeck, for instance, who was more of a speculative and contemplative nature. ${ }^{39}$ In a time when scholasticism is languishing, the Imitation of Christ points to a better way. It is part of a movement that, according to Luther and Melancthon, was "an important stage in the religious development of the German people, and it is certainly most significant that the Reformation broke out on the soil where the mystics lived and wrought, and their piety took deep root." 40

There are two things that make their marks on the Reformation. One is the high view of Scripture, and the other in relation to it, is the role of vernacular language.

It is said of de Groote that he went to the Scriptures as to a well of life. ${ }^{41}$ The author of the Imitation of Christ quoted from the Scriptures at least 53 times, from the New Testament more (30 times) than from the Old Testament (23 times), as the mystics used to $\mathrm{do}^{42}$ and the one book he quotes most from is the Psalms (13 times). German mystics put Christ in the place of the Church, as the mediator between the soul and God. ${ }^{43}$

The Brothers of the Common Life gave a special place for the mother-tongue ${ }^{44}$ which Luther emphasized, saying, "I thank God that I have heard and find my God in the German tongue." ${ }^{45}$ The Imitation of Christ is supposed to have been translated into Latin from Dutch, another vernacular language. ${ }^{46}$

\footnotetext{
Kempis, book 4, chapter 1 .

Kempis, book 4, chapter 7.

Kempis, book 4, chapter 13.

Schaff, 199, 225.

Ibid., 198.

Ibid., 229.

Ibid., 198.

Ibid., 198.

Ibid., 229

Ibid., 198.

Kempis, Preface.
} 
The Imitation of Christ attracts people with its gentle tone, humility, and honesty. The humility is not only unique of the Imitation of Christ, but is characteristic of the German mysticism. ${ }^{47}$ Here is an example of honest humility by the author: "Pardon me also, and deal mercifully with me, as often as I think of anything besides You in prayer. For I confess truly that I am accustomed to be very much distracted. Very often I am not where bodily I stand or sit; rather, I am where my thoughts carry me. Where my thoughts are, there am I; and frequently my thoughts are where my love is. That which naturally delights, or is by habit pleasing, comes to me quickly. Hence You Who are Truth itself, have plainly said: "For where your treasure is, there is your heart also." If I love heaven, I think willingly of heavenly things. If I love the world, I rejoice at the happiness of the world and grieve at its troubles. If I love the flesh, I often imagine things that are carnal. If I love the spirit, I delight in thinking of spiritual matters. For whatever I love, I am willing to speak and hear about." 48

\section{Influence}

There is a number of famous names who have acknowledged the Imitation of Christ as influential in their lives, like Dr. Samuel Johnson, John Wesley, and John Newton. ${ }^{49}$ Fitzgerald believes that Shakespeare is influenced by the Imitation of Christ. ${ }^{50}$ In the book there is a practical application of the golden rule regarding other people, "Try to bear patiently with the defects and infirmities of others, whatever they may be, because you also have many a fault which others must endure. If you cannot make yourself what you would wish to be, how can you bend others to your will? We want them to be perfect, yet we do not correct our own faults." ${ }^{11} \mathrm{C}$. S. Lewis adopted this principle and used it in his writing.

The great significance of the Imitation of Christ lies in its great practical value. The book is not without theological convictions, but the general attitude of the book is one so warm that it avoids what theological debates often accomplish, namely shutting people out. It is a wonderful source of quotes. A favorite of the author of this article is: "If we were to uproot only one vice each year, we should soon become perfect." ${ }^{52}$ Fitzgerald thinks the book is very businesslike in dealing with matters of salvation. ${ }^{53}$ The book on

\footnotetext{
Schaff, 198.

Kempis, book 4, chapter 48.

Schaff, 232.

Fitzgerald, 4.

Kempis, book 1 , chapter 16 .

Kempis, book 1, chapter 11 .

Fitzgerald, 36.
} 
Sacrament compels us to examine ourselves of sin and make a commitment to give ourselves wholly to the Lord.

If Thomas a Kempis was the author, his being a quiet man probably helps him to be sensitive to faults that manifest themselves in the opposite of quiet (from busybody to people attempting all sorts of feats in order to obtain a good reputation, for instance). This does not mean being quiet is all there is to Christian life. But it also does not mean that we should disregard his wisdom as a mere subjective bias. God gives people in different dispositions and callings throughout the church in all times and places, and there is something in everyone that would contribute to the building up of the church. The Imitation certainly has done its part.

\section{Relevance for Today}

"Never read them [the Scriptures] for the purpose of appearing more learned or more wise." ${ }^{54}$ Many people today ask questions about the Bible just out of curiosity and not from a willingness to obey. The author of this article did read the Bible without always seeing commands as commands. She could be too busy looking for inspirations towards the logic of the command, or for the touching love for God, or other things, that commands do not appear to her first of all as commands - something that, first of all, must be done. What the Imitation says hundreds of years ago, remains relevant today.

Another important aspect of the Imitation of Christ that is very appealing to the postmodern era is its honesty. There is honesty to admit that we do not know everything, which can actually help bridge the gap between sinners. There is another level of honesty; admitting what we are. As Fitzgerald pointed out, "To find a remedy he goes to the very root of the matter - not to fresh resolutions, or new efforts and exertions of strength: but to make admission that we have no strength and no resolution! For we must humble ourselves, and never think anything great of ourselves." Having made this discovery, and being convinced of its truth, we may set to work afresh." ${ }^{\prime 5}$ Instead of proposing solutions that would keep the honor of its listeners intact, as well as the veiled sin of their hearts, the Imitation reminds us what we would prefer to forget: that we are sinners.

Last, but not least, the primacy of Christ can be seen even in the style this work is made. It is not strange that people would write diaries, or spiritual diaries, but to imagine Christ speaking there is a great help to ponder on how He sees us. It is heartwarming to think that Christ listens to all the

54 Kempis, book 3, chapter 33.

55 Fitzgerald, 68. 
outpouring of our heart as gently and patiently as only a diary could, and encouraging to be assured that God knows all that goes on in our life. 